
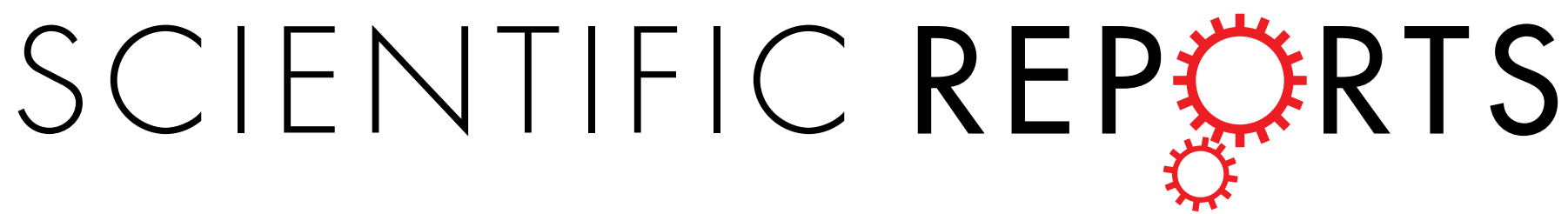

\title{
OPEN
}

Received: 19 June 2018

Accepted: 7 November 2018

Published online: 21 November 2018
Seasonal succession of ciliate

\section{Mesodinium spp. with red, green, or mixed plastids and their association with cryptophyte prey}

Goh Nishitani ${ }^{1} \&$ Mineo Yamaguchi ${ }^{2}$

Mesodinium spp. are commonly found in marine and brackish waters, and several species are known to contain red, green, or both plastids that originate from cryptophyte prey. We observed the seasonal succession of Mesodinium spp. in a Japanese brackish lake, and we analysed the origin and diversity of the various coloured plastids within the cells of Mesodinium spp. using a newly developed primer set that specifically targets the cryptophyte nuclear 18S rRNA gene. Mesodinium rubrum isolated from the lake contained only red plastids originating from cryptophyte Teleaulax amphioxeia. We identified novel Mesodinium sp. that contained only green plastids or both red and green plastids originating from cryptophytes Hemiselmis sp. and Teleaulax acuta. Although the morphology of the newly identified Mesodinium sp. was indistinguishable from that of $M$. rubrum under normal light microscopy, phylogenetic analysis placed this species between the $M$. rubrum/major species complex and a wellsupported lineage of $M$. chamaeleon and $M$. coatsi. Close associations were observed in cryptophyte species composition within cells of Mesodinium spp. and in ambient water samples. The appearance of suitable cryptophyte prey is probably a trigger for succession of Mesodinium spp., and the subsequent abundance of Mesodinium spp. appears to be influenced by water temperature and dissolved inorganic nutrients.

Ciliates belonging to genus Mesodinium are widely distributed and are abundant in marine and brackish waters $^{1,2}$. The most common species, Mesodinium rubrum Lohmann 1908 (previously named as Myrionecta rubra Jankowski 1976), causes red water blooms in many coastal ecosystems. Although M. rubrum is known as a nontoxic species ${ }^{3}$, blooms of the ciliate can be potentially harmful to aquaculture industries ${ }^{4,5}$. M. rubrum is reported to photosynthesize by sequestering the nucleus of its cryptophyte prey, in order to maintain stolen plastids and other organelles ${ }^{6}$. Therefore, the genus Mesodinium plays an important role in linking cryptophycean prey and diverse predators in the aquatic microbial food web. For example, the dinoflagellates Dinophysis spp., which are a predator of M. rubrum and the source of their cryptophyte-derived plastids, have been frequently observed to be precede or to coincide with high densities of M. rubrum in time and space ${ }^{7-10}$.

Currently, six marine species of Mesodinium have been described and are grouped based on nutritional mode: plastidic (M. chamaeleon, M. coatsi, M. major, and M. rubrum) or heterotrophic (M. pulex and M. pupula). There is some debate as to whether the nutritional mode of plastidic Mesodinium species is phototrophic (permanent plastid) or mixotrophic ${ }^{11,12}$. Among the plastidic species, wild M. major and M. rubrum populations possess red plastids belonging to genera Teleaulax, Plagioselmis, and Geminigera ${ }^{13-15}$, while wild M. chamaeleon and M. coatsi populations normally contain green plastids ${ }^{16-18}$. Under laboratory conditions, M. chamaeleon and $M$. coatsi were maintained by providing the green cryptophyte prey, Chroomonas vectensis and Chroomonas sp., respectively ${ }^{17,18}$. In another case, $M$. chamaeleon grew best with a red cryptophyte, Storeatula major, in the laboratory experiment ${ }^{19}$. Therefore, the availability of suitable cryptophyte prey is important for bloom formation of plastidic Mesodinium species.

${ }^{1}$ Graduate School of Agricultural Science, Tohoku University, Aoba 468-1, Aramaki, Aoba-ku, Sendai, 980-0845, Japan. ${ }^{2}$ School of Marine Biosciences, Kitasato University, 1-15-1 Kitasato, Minami-ku, Sagamihara, Kanagawa, 2520373, Japan. Correspondence and requests for materials should be addressed to G.N. (email: ni5@tohoku.ac.jp) or M.Y. (email: mineo@kitasato-u.ac.jp) 

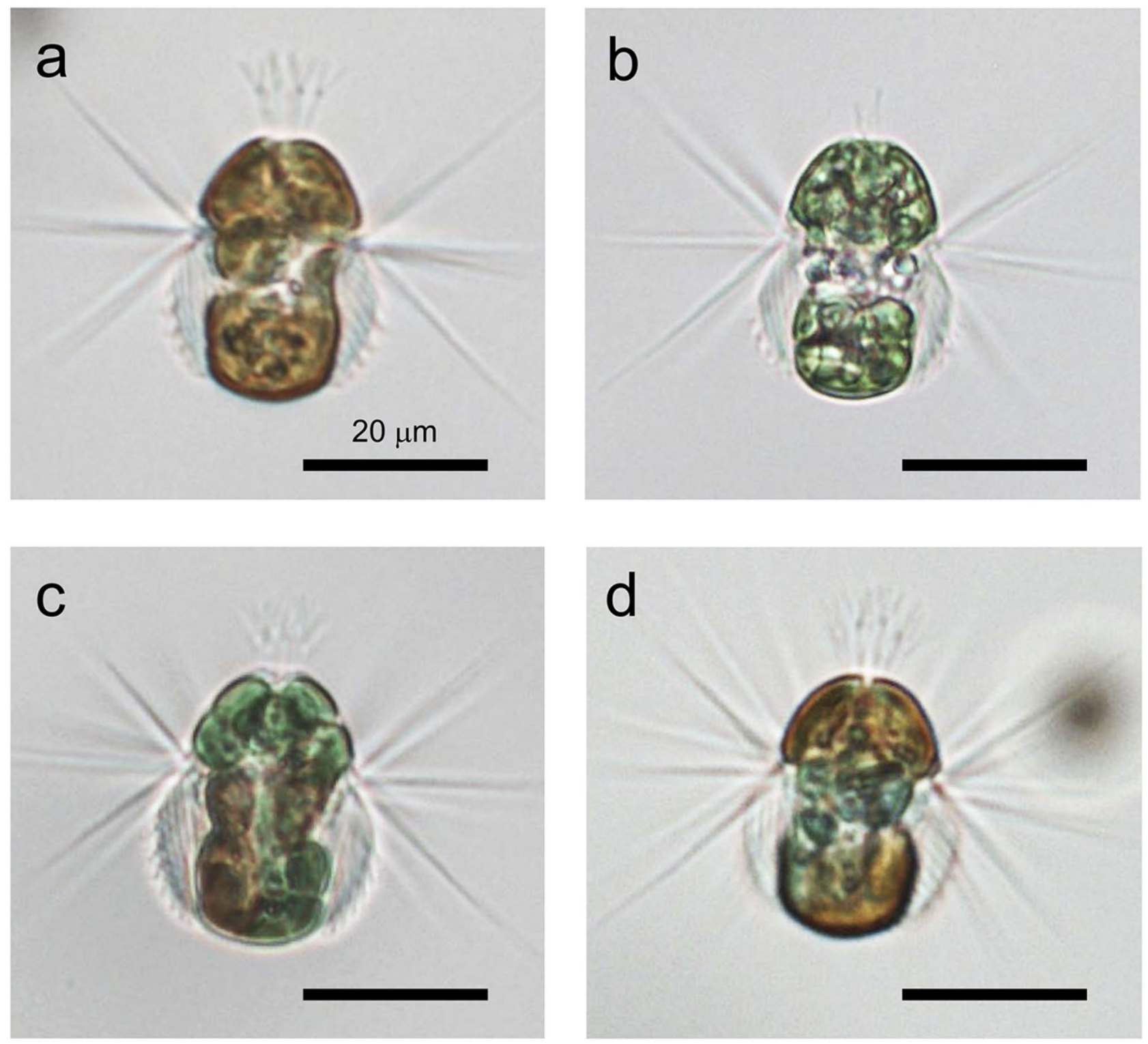

Figure 1. Cells of Mesodinium spp. collected from the brackish water of Lake Koyama, Japan. Mesodinium contained red $(\mathbf{a})$, green $(\mathbf{b})$, or red and green $(\mathbf{c}, \mathbf{d})$ plastids derived from cryptophyte prey. All scale bars $=20 \mu \mathrm{m}$.

We recently noticed that Mesodinium spp. appearing in a Japanese brackish lake possess red or green plastids, or a combination of both (Fig. 1), and the ratio of coloured plastids varied depending on season. This phenomenon poses two intriguing questions: (i) the identify of the originating cryptophyte species of the plastids, and (ii) whether the different coloured Mesodinium are the same species. To date, although there are many studies on cultivating Mesodinium using cryptophyte prey under laboratory conditions, few studies have documented cryptophyte diversity and the associations between cryptophytes and Mesodinium in the field. Herfort et al. ${ }^{14}$ investigated cryptophyte diversity in water samples and within cells of Mesodinium using a universal primer set targeting the nuclear 18S rRNA gene. Although sequences of the $18 \mathrm{~S}$ rRNA gene are abundantly available in the GenBank database, this assay is not specific to cryptophyte species and also amplifies diatoms and dinoflagellates. Molecular detection using cryptophyte-specific primer sets targeting the nucleomorph $18 \mathrm{~S}$ rRNA gene, the plastid $r b c L$ gene, and the nuclear $28 \mathrm{~S}$ rRNA gene has also been reported ${ }^{13,15,20}$. However, these regions are more difficult to identify in cryptophyte species because compared to the nuclear $18 \mathrm{~S}$ rRNA gene, there are few sequences in the GenBank database.

Therefore, in this study, we first developed a new primer set that specifically amplifies part of the cryptophyte nuclear 18S rRNA gene. This primer set has two advantages: (i) it possesses specificity to cryptophytes and (ii) it produces amplification products that can be aligned with database sequences for species identification of cryptophytes. Using the cryptophyte-specific primer set, we analysed the origin of cryptophyte plastids and their diversity within the cells of Mesodinium and also the diversity of cryptophytes in water samples. We also conducted species identification of Mesodinium spp. using Mesodinium-specific primer sets. Finally, these results were used 

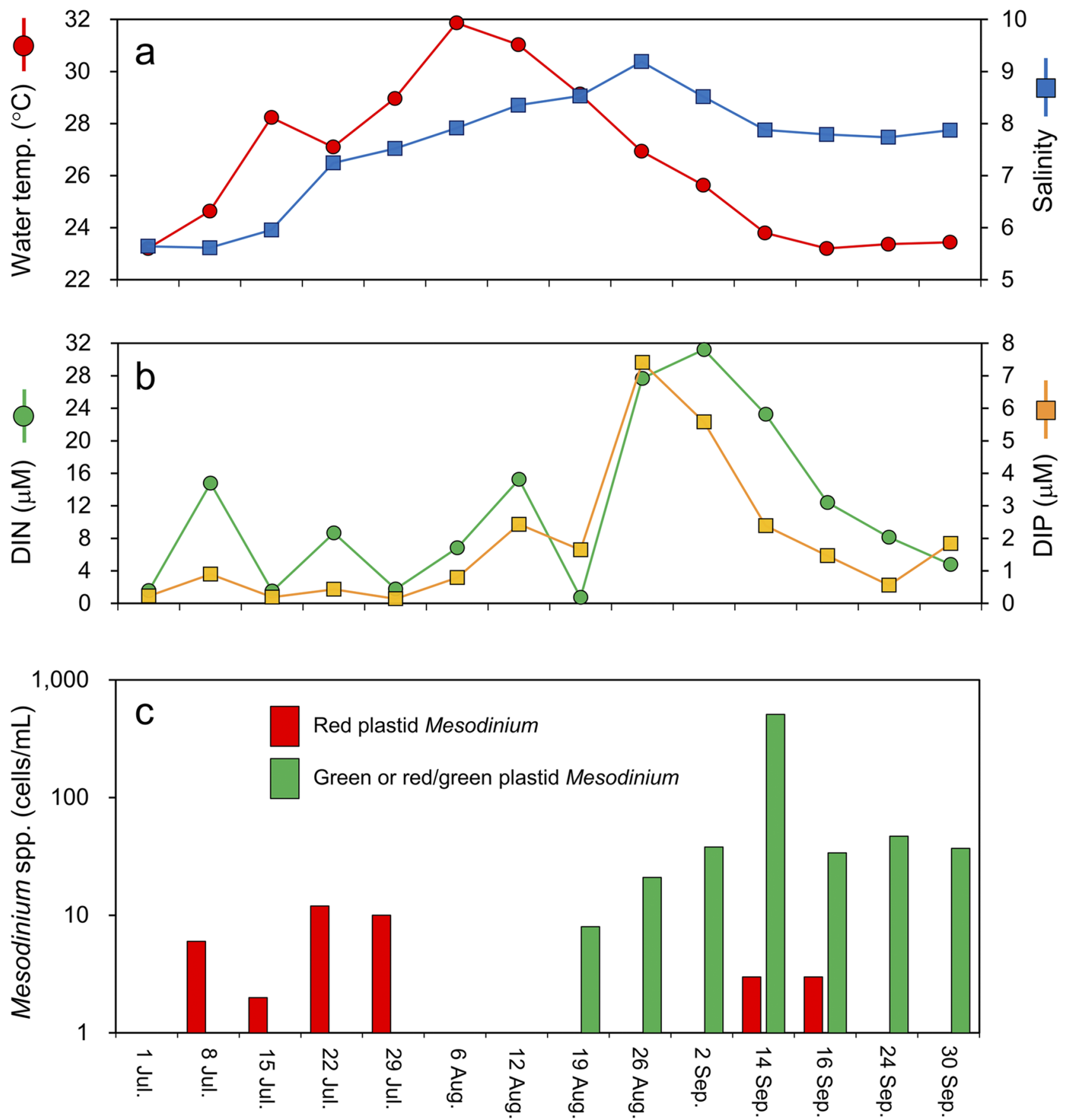

Figure 2. Seasonal changes in environmental factors and cell density of Mesodinium spp. in the brackish lake from July to September 2015. (a) Water temperature and salinity, (b) DIN and DIP, and (c) cell density of Mesodinium spp. for red plastid-containing Mesodinium or for Mesodinium with other plastid types were determined throughout the sampling season.

to deduce the prey preference of Mesodinium and the role of cryptophytes on the succession of Mesodinium species in the field.

\section{Results}

Environmental data and seasonal succession of Mesodinium populations. Environmental data, including water temperature, salinity, and dissolved inorganic nutrients (DIN and DIP) are shown in Fig. 2. During the sampling period, water temperature ranged from 23.2 to $31.9^{\circ} \mathrm{C}$, and salinity ranged from 5.6 to 9.2. Water temperature gradually increased from the start of the sampling ( 1 July) to the maximum value on 6 August and then decreased. No marked variation was observed in salinity with a slight increase toward to the end of the 


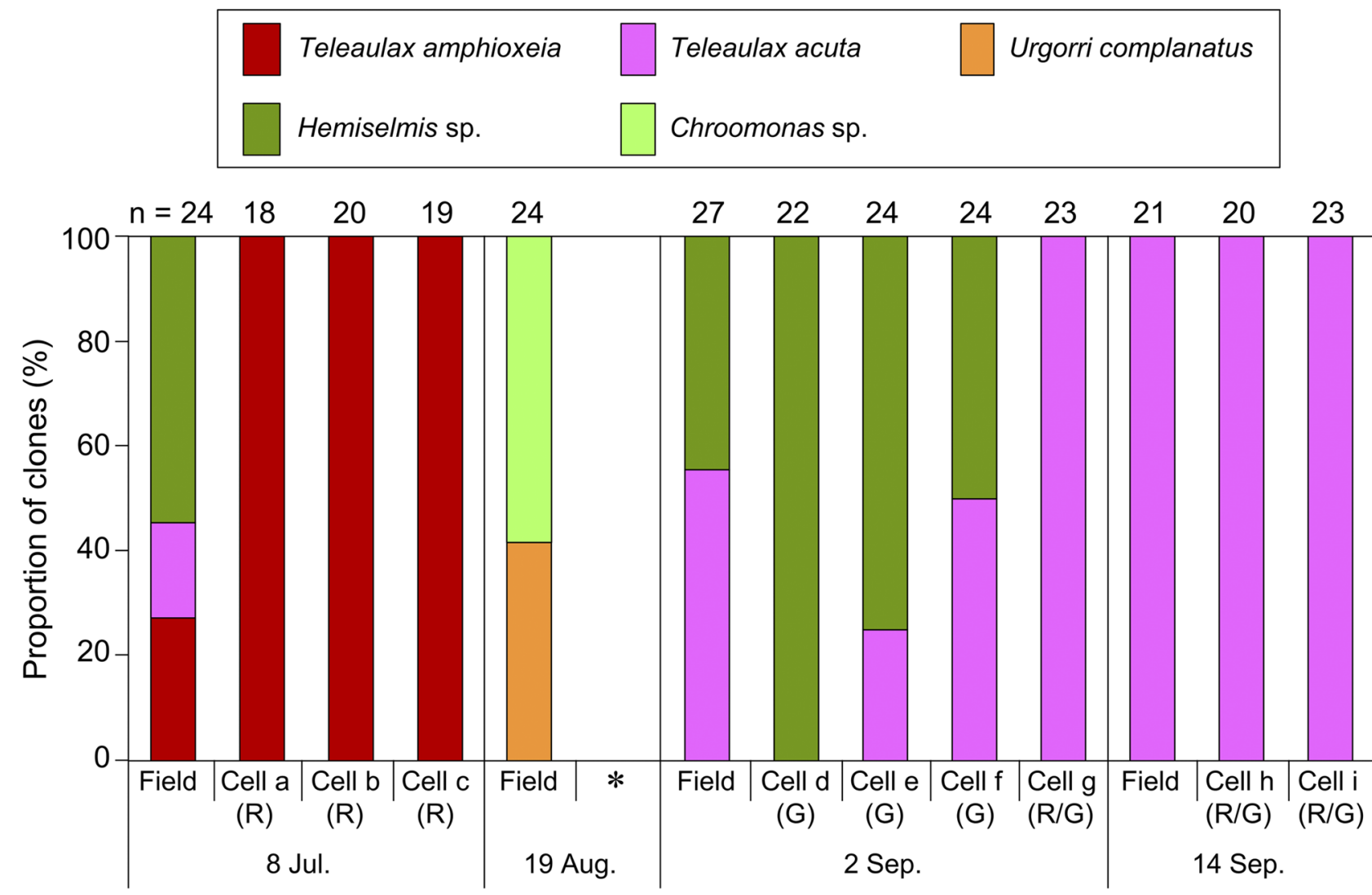

Figure 3. Species distribution of cryptophyte clones recovered from the nine cells of Mesodinium (cells a-i) and the water samples (Field), based on the partial nuclear 18S rRNA gene sequence. On 19 August, no Mesodinium cells could be isolated (indicated by the asterisk). Plastid colour is represented by red (R), green (G), or red and green $(R / G)$. The " $n$ " indicates the number of sequenced clones.

sampling period. DIN ranged from 0.42 to $31.22 \mu \mathrm{M}$ and DIP ranged from 0.07 to $7.40 \mu \mathrm{M}$. Dissolved nutrients were relatively low in the first half of the sampling period and increased in the latter half.

In this brackish lake, the presence of M. rubrum-like ciliates was confirmed, and they had three different plastid patterns based on colour: red plastids (Fig. 1a), green plastids (Fig. 1b), or both red and green plastids (Fig. 1c,d). An increase in red-coloured Mesodinium was first observed at the start of the sampling period, and then the population was replaced by green and mixed-coloured Mesodinium in the latter half (Fig. 2). The maximum cell density of red-coloured Mesodinium was 12 cells/mL on 22 July, while the green and mixed-coloured Mesodinium reached 510 cells/mL on 14 September. Re-occurrences of red-coloured Mesodinium were observed on 14 and 16 September although the densities were relatively low $(3$ cells $/ \mathrm{mL})$. A statistically significant correlation was observed between the cell density of the green and mixed-coloured Mesodinium and DIN concentration: $\mathrm{r}=0.42(\mathrm{P}=0.028)$.

Genetic analyses of cryptophyte diversity within the cells of Mesodinium spp. and in water samples. A total of 193 cryptophyte sequences were determined from nine cells of Mesodinium, and a total of 96 cryptophyte sequences were identified from water samples by cloning (Fig. 3).

The three cells of Mesodinium (a, b, and c) collected on 8 July, the beginning of the sampling period, had red-colour plastids and all 57 obtained sequences were of T. amphioxeia. However, the filter sample from that date included three cryptophytes species, T. amphioxeia, T. acuta and Hemiselmis sp. On 18 August, no Mesodinium cells could be isolated due to the scarcity of cells, and the cryptophyte sequences recovered from the water sample included Urgorri complanatus and Chroomonas sp. The cryptophyte U. complanatus is a red-tide-forming species in brackish waters, with the red plastid colour due to the presence of phycoerythrin ${ }^{21}$, while Chroomonas species have green plastids due to the presence of phycocyanin ${ }^{22}$. On 2 September, of the four cells of Mesodinium (d, e, $\mathrm{f}$, and g) that were isolated, three cells (d, e, and f) had only green-colour plastids, and one cell (g) had both red and green plastids. In the 93 cryptophyte sequences recovered from four cells of Mesodinium, the sequences of $T$. acuta and Hemiselmis sp. but not T. amphioxeia were recovered. The sequence of Hemiselmis sp. showed $98.7 \%$ similarity to that of $H$. cryptochromatica, which possesses green plastids ${ }^{22}$. Cryptophyte diversity within the cells of Mesodinium was relatively well consistent with that in the water sample collected on the same day. On 14 September, two cells of Mesodinium had mix-coloured (red and green) plastids, although both cells and the water sample only had cryptophyte sequences of T. acuta. 
88

97

M. cf. major KP721512

M. rubrum MR-MAL01 EF195734

M. rubrum 15KY (Cell a-c) LC341273

95 M. rubrum CBJR05 KX781269

M. rubrum Mr-DK2007 JN412736

100

M. rubrum CCMP2563 JN412738

M. rubrum AY587129

Clade

100

Mesodinium sp. 15KY (Cell d-i) LC333818

M. chamaeleon JN084213

100

M. coatsi KF836430

M. pulex JN412740

M. pupula JN412739

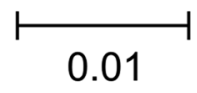

Figure 4. Unrooted maximum likelihood phylogenetic tree of the nuclear 18S rRNA gene of Mesodinium spp. analysed in this study together with sequences from the GenBank database. Sequences determined in this study are highlighted in gray. Clades (A, B, D, F, and G) are as referenced by Herfort et al. ${ }^{14}$ and Johnson et al. ${ }^{20}$ within the M. major/rubrum complex. Bootstrap values of $>50 \%$ on the tree produced using MEGA software ver. 7 are given as the percentage of 100 bootstrap replicates at the respective nodes. The final dataset contains 1,218 informative sites. The scale bar represents the number of substitutions per site.

Genetic analysis of nine cells of Mesodinium for species identification. Although the morphology of nine cells of Mesodinium that we isolated was consistent with that of M. rubrum, the period of occurrence and plastid characteristics were clearly different. Therefore, we confirmed the species of all nine cells of Mesodinium by sequencing the nuclear $18 \mathrm{~S}$ rRNA gene sequences. Three cells $(\mathrm{a}, \mathrm{b}$, and $\mathrm{c}$ ) that were isolated in the beginning of the sampling period were identical to the sequences of M. rubrum (variant B) catalogued as AB364286 in GenBank. The sequences of the remaining six cells ( $d, e, f, g, h$, and i) were identical to each other but were not identical with any variants in $M$. rubrum or environmental sequences catalogued in GenBank.

We tentatively identified the novel sequence as Mesodinium sp., and the sequence had 15-22/1483 bp differences (similarity: 98.5-99.0\%) with those of variants in M. rubrum. The phylogenetic position within the genus Mesodinium is represented in Fig. 4. As shown previously ${ }^{16}$, genus Mesodinium formed four distinct clades represented by M. pulex, M. pupula, M. chameleon/M. coatsi, and the M. major/rubrum complex, respectively. Furthermore, the M. major/rubrum species complex was divided into eight subclades based on 18S rRNA gene fragment, the complete internally transcribed spacer region, and a partial region of the $28 \mathrm{~S}$ rRA gene ${ }^{14,16,20}$. At present, nearly complete $18 \mathrm{~S}$ rRNA gene sequences are available in five (variants A, B, D, F, and G) out of the eight subclades. The novel sequence of Mesodinium sp. analysed in this study was not grouped with any variants of the M. major/rubrum species complex on the phylogenetic tree, which had $88 \%$ bootstrap support (Fig. 4).

\section{Discussion}

Here, we showed that the newly observed Mesodinium is not as a variant of M. rubrum but a novel species "Mesodinium sp.". While this species could not be distinguished from M. rubrum based on morphology under normal light microscopy, it could be clearly differentiated based on ecology, especially plastid origin. Previous field investigations revealed that natural cells of M. rubrum possess plastids originating from cryptophyte Teleaulax amphioxeia ${ }^{13,14}$. Furthermore, to date, all stable cultures of $M$. rubrum have been established using either Teleaulax or Geminigera as prey ${ }^{23-28}$, both of which are closely related and have red plastids that contain phycoerythrin biliprotein. To date, there have been no reports on the culture of M. rubrum with green-plastid cryptophytes as a prey. We also tried to cultivate Mesodinium sp. isolated from the brackish lake using filtered sterilized 


\begin{tabular}{|l|l|l|}
\hline Primer name & Sequence $\left(\mathbf{5}^{\prime} \mathbf{~}^{\prime} \mathbf{}^{\prime}\right)$ & Annealing site \\
\hline n18S-Crypt24F & ATTAAGCCATGCATGTCTTAGTG & $24-46^{\mathrm{a}}$ \\
\hline $\mathrm{n} 18 \mathrm{~S}-$-Crypt860R & CTCTGACAACGAAATATRAACGG & $838-860^{\mathrm{a}}$ \\
\hline $\mathrm{n} 18 \mathrm{~S}-$ Meso1F & AACCTGGTTGATCCTGCCAG & $1-20^{\mathrm{b}}$ \\
\hline $\mathrm{n} 18 \mathrm{~S}-$ Meso580R & ACGACGTACAGACTACGGACGT & $559-580^{\mathrm{b}}$ \\
\hline $\mathrm{n} 18 \mathrm{~S}-$ Meso470F & TTCCKATTAGCAACTGATGGGA & $470-491^{\mathrm{b}}$ \\
\hline $\mathrm{n} 18 \mathrm{~S}-$ Meso1108R & GTCATYAGCCTGTCAATCACGC & $1087-1108^{\mathrm{b}}$ \\
\hline $\mathrm{n} 18 \mathrm{~S}-$ Meso1006F & TTGACGGAAGAGCACCATAAGAC & $1006-1028^{\mathrm{b}}$ \\
\hline $\mathrm{n} 18 \mathrm{~S}-$ Meso1580R & TCACCTACGGAAACCTTGTTACG & $1558-1580^{\mathrm{b}}$ \\
\hline
\end{tabular}

Table 1. Primers used in this study. The annealing sites refer to the sequences of Teleaulax amphioxeia AJ007287 (a) and Mesodinium pulex DQ845294 (b) in GenBank. All primers were newly developed in this study.

lake water and a culture strain of green-plastid cryptophyte Chroomonas sp. as a prey that had been isolated from the same area (Supplementary Table S1). The 18S rRNA gene sequence of the Chroomonas sp. was identical to that detected by gene cloning from the field analysis on 19 August. Mesodinium sp. could only be maintained for 3 weeks with the green-plastid cryptophyte Chroomonas sp. Our genetic analysis (Fig. 3) shows that green-coloured Mesodinium sp. possessed the plastid originated from the genus Hemiselmis not Chroomonas, suggesting that cryptophyte prey may not be suitable for supporting the growth of Mesodinium sp. We then attempted to cultivate Mesodinium sp. with red-plastid cryptophyte Teleaulax amphioxeia (Supplementary Table S1). The culture strain of Mesodinium sp. with T. amphioxeia was maintained for 1 year and 4 months, but this prey did not seem to be optimal. Given that the DNA of T. acuta was detected from the natural cells of Mesodinium sp. by genetic analysis in this study, Mesodinium sp. may have species-level Hemiselmis and Teleaulax prey preference for supporting optimal growth, while $M$. rubrum shows Teleaulax genus-level selection ${ }^{28}$. Finally, we consider that $M$. rubrum-like ciliates containing green plastids, namely Mesodinium sp., are distinct species from M. rubrum based on sequence difference and their capability for utilizing plastids from Hemiselmis cryptophytes, although further experiments such as observations of ultrastructure and growth physiology are required to confirm the true differentiation of species or as a variant thereof. Yih et al. have reported an interesting observation that natural cells of M. rubrum collected from Gomso Bay, Korea had different plastid colours (red, green, or a combination) ${ }^{29}$, although they did not analysed the DNA sequences of the cells of M. rubrum. Such M. rubrum-like ciliates possessing green plastids might also have a distinct $18 \mathrm{~S}$ rRNA gene sequence, as shown in this study.

Our field monitoring and genetic analysis revealed that the seasonal succession from M. rubrum to Mesodinium sp. occurred in a brackish lake, despite the indistinguishable morphology. The abundance of both species seems to be related to water temperature and dissolved inorganic nutrients. Water temperature during the sampling period $\left(23.2-31.9^{\circ} \mathrm{C}\right)$ in Lake Koyama was higher than the optimum growth temperature of Mesodinium, especially when the water temperature exceeded $28^{\circ} \mathrm{C}$. Johnson et al. have reported that the highest concentrations $(>1000$ cells $/ \mathrm{mL})$ of $M$. rubrum were observed when the average water temperature in Chesapeake Bay was $18.1^{\circ} \mathrm{C}^{30}$. In laboratory experiments, culture experiments of M. rubrum are typically conducted in temperatures ranging from 15 to $18^{\circ} \mathrm{C}^{26,31-33}$. The dissolved inorganic nutrients (DIN and DIP) may also influence the growth of Mesodinium. Tong et al. reported that DIN and DIP can be utilized by M. rubrum for enhanced growth when requirements for optimal cryptophyte prey are met ${ }^{33}$. Previous studies have found that ingestion of cryptophytes represents less than $10 \%$ of the required carbon requirements for $M$. rubrum growth and maintenance 31,34 , indicating the importance of dissolved inorganic nutrients for autotrophic growth of $M$. rubrum. In contrast, $M$. chamaeleon obtains about half of its energy from photosynthesis, and its growth is not affected by dissolved inorganic nutrients ${ }^{19}$. In this study, the increase in cell number of Mesodinium sp. observed in the latter half of the sampling period might be attributable to the increased DIN and DIP (Fig. 2), either directly or indirectly (i.e. by stimulating growth of optimal prey). However, further laboratory studies are needed to address the role of nutrients in this novel Mesodinium sp.

Sequences of three cryptophyte species, T. amphioxeia, T. acuta, and Hemiselmis sp., were detected in the water sample collected on 8 July, however, only T. amphioxeia was detected from three cells of M. rubrum collected on the same day. This observation suggests that M. rubrum preferentially ingested T. amphioxeia as previously reported in the field ${ }^{13,14}$ and laboratory ${ }^{24,26-28}$. On the other hand, Mesodinium sp. analysed in this study possessed either red or green plastids, or both, depending on the cryptophyte species present; $M$. chamaeleon showed a similar pattern in laboratory experiments ${ }^{17,19}$. Although the morphology of Mesodinium sp. was remarkably similar to that of M. rubrum, it seems to resemble M. chamaeleon in the plastid utilization.

The growth physiology and plastid replacement of Mesodinium sp. under laboratory cultivation is of particular interest when suitable red and green cryptophyte, T. acuta and Hemiselmis sp., are supplied. On 14 September, T. acuta was the only cryptophyte detected in both the water sample and the cells of Mesodinium sp., while the cells of Mesodinium contained both red and green plastids. Since the nucleus of cryptophyte prey has been shown to be lost over time in M. rubrum ${ }^{6}$ and degraded rather quickly in M. chamaeleon ${ }^{17}$, any nucleus associated with the green plastids of isolated Mesodinium sp. were probably older than the red ones, and their DNA may have been too low to be amplified by PCR.

In conclusion, M. rubrum preferentially ingests red plastid cryptophytes, especially T. amphioxeia, in the field, while Mesodinium sp. analysed in this study utilized both red and green plastid cryptophytes as prey. Although the morphology of the present sample and M. rubrum could not be distinguishable under normal light microscopy, the $18 \mathrm{~S}$ rRNA gene sequences had 15-22/1483 bp differences. The appearance of suitable cryptophyte prey 
is likely the most important factor for succession of Mesodinium spp., and the abundance of Mesodinium appears to be influenced by water temperature and perhaps dissolved inorganic nutrients.

\section{Methods}

Sample collection and water chemistry. Lake Koyama $\left(35^{\circ} 30^{\prime} \mathrm{N}, 134^{\circ} 9^{\prime} \mathrm{E}\right)$ in Tottori Prefecture, southwest Japan, is a brackish lake with a mean depth of $2.8 \mathrm{~m}$ and is one of the largest lakes in Japan. Water samples were collected from the surface layer from July to September 2015. Water temperature and salinity were measured with a multi-parameter water quality sonde (Hydrolab DS5, OTT Hydromet, Germany). Dissolved inorganic nitrogen (DIN) and dissolved inorganic phosphorous (DIP) were determined using an AutoAnalyzer (TRACCS-2000, BL TEC, Japan) after filtering water samples through a membrane filter $(0.45 \mu \mathrm{m}$, Millipore, USA).

Cell enumeration. Live cell density of Mesodinium spp. was determined separately for each plastid colour under an inverted microscope (Nikon Eclipse Ti-U, Japan). However, green cells and the cells with both coloured plastids (green/red) were counted together due to the difficulty of distinguishing cells with green only or mixed green and red plastids. Enumeration of cell density in cryptophytes was not conducted in this study.

Sample collection for DNA analysis. For the DNA analysis, two types of samples were prepared: (i) PCR tubes containing a single cell of Mesodinium to analyse cryptophyte prey diversity within the ciliate cell and for species identification of Mesodinium and (ii) membrane filters through which water samples were filtered to analyse cryptophyte diversity in surface water. In the single cell analysis, a total of nine cells of Mesodinium were isolated by micropipetting on the following dates in 2015: 8 July (cells a, b, and c), 2 September (cells d, e, f, and g), and 14 September (cells h and i). The live cells were washed several times with filtered $(0.1 \mu \mathrm{m}$ pore size) seawater and placed individually in $0.2 \mathrm{~mL}$ PCR tubes containing $10 \mu \mathrm{L}$ of TE buffer (Tris-hydrochloride buffer, $\mathrm{pH}$ 8.0, containing 1.0 mM EDTA). In the membrane filter analysis, samples were obtained on the following dates in 2015: 8 July, 19 August, 2 September, and 14 September. Each $50 \mathrm{~mL}$ aliquot of water was passed through a plankton net $(20 \mu \mathrm{m}$ mesh size) to remove large organisms and filtered through a membrane filter $(25 \mathrm{~mm}$ diameter with $1 \mu \mathrm{m}$ pore size; Nuclepore Track-Etch Membrane, Whatman plc, UK). All PCR tubes and filters were stored at $-25^{\circ} \mathrm{C}$ until DNA extraction.

DNA extraction, PCR amplification, and gene cloning. DNA was extracted from single cell samples by heating at $98^{\circ} \mathrm{C}$ for $20 \mathrm{~min}$ and from filters using the DNeasy Plant Mini Kit (Qiagen, Germany). We have developed a new cryptophyte-specific primer set (n18S-Crypt24F/n18S-Crypt860R; Table 1) that specifically amplifies a portion of the nuclear 18S rRNA gene of cryptophytes and can be used for the analysis of cryptophyte diversity in field samples, as well as within cells of Mesodinium. This primer set was designed not to amplify the nucleomorph gene of cryptophytes. The newly designed primer set was shown to be effective in this study because no sequences other than cryptophyte sequences were detected in field and Mesodinium samples. First, the cryptophyte diversity within each cell of Mesodinium was analysed using DNA from the PCR tubes with the newly developed primer set. Single-cell polymerase chain reaction (PCR) was performed using a Veriti thermal cycler (Thermo Fisher Scientific, USA) with a reaction mixture $(20 \mu \mathrm{L})$ containing $1.0 \mu \mathrm{L}$ template DNA, $0.2 \mathrm{mM}$ of each dNTP, $1 \times$ PCR buffer, $1.5 \mathrm{mM} \mathrm{Mg}^{2+}, 1.0 \mathrm{U}$ KOD -Plus- ver. 2 (TOYOBO, Japan, with intensive $3^{\prime} \rightarrow 5^{\prime}$ exonuclease activity), and $0.2 \mu \mathrm{M}$ of each primer. The PCR amplification conditions were as follows: initial denaturation at $94^{\circ} \mathrm{C}$ for $2 \mathrm{~min}$, followed by 32 cycles of $98^{\circ} \mathrm{C}$ for $10 \mathrm{~s}, 56^{\circ} \mathrm{C}$ for $30 \mathrm{~s}$, and $68^{\circ} \mathrm{C}$ for $60 \mathrm{~s}$. The resulting PCR amplifications were run on $1.5 \%$ agarose gels, and gene cloning was then conducted according to Nishitani et al. ${ }^{35}$. Second, cryptophyte diversity in each water samples was analysed using DNA from the filters with the same primer set (n18S-Crypt24F/n18S-Crypt860R) and amplification conditions and gene cloning as described above. Finally, the species of the nine cells of Mesodinium were identified using DNA from the PCR tubes targeting the nuclear 18S rRNA gene with specific primer sets for Mesodinium (three primer sets were designed in this study: n18S-Meso1F/n18S-Meso580R, n18S-Meso470F/n18S-Meso1108R, and n18S-Meso1006F/ n18S-Meso1580R; Table 1). These primer sets specifically amplify DNA of genus Mesodinium even if cryptophyte DNA is present in the ciliate. PCR amplification conditions were as follows: initial denaturation at $94^{\circ} \mathrm{C}$ for $2 \mathrm{~min}$, followed by 34 cycles at $98^{\circ} \mathrm{C}$ for $10 \mathrm{~s}, 60^{\circ} \mathrm{C}$ for $30 \mathrm{~s}$, and $68^{\circ} \mathrm{C}$ for $45 \mathrm{~s}$. PCR products were then purified using the ExoSAP-IT PCR product cleanup reagent (Thermo Fisher Scientific, USA). The DNA sequences of Mesodinium spp. were determined directly, without gene cloning. All sequences obtained in this study were determined using a DYEnamic ET Terminator Cycle Sequencing Kit (GE Healthcare, Little Chalfont, UK) and analysed on a 3730xl DNA Analyzer (Thermo Fisher Scientific, USA).

Phylogenetic analysis. All PCR amplification products were sequenced, and the forward and reverse sequences were aligned using GENETYX software (Genetyx Corporation, Japan). All cryptophyte sequences obtained in this study were checked against GenBank using the nucleotide Basic Local Alignment Search Tool (BLASTN). To deduce the species of Mesodinium analysed in this study, sequences of the 18S rRNA gene for Mesodinium were aligned and an unrooted phylogenetic tree was generated by MEGA ver. 7 software ${ }^{36}$ using the maximum likelihood (ML) method with default settings. The topology of the phylogenetic tree was evaluated using the bootstrap method, with 100 replicates.

\section{Data Availability}

All sequences obtained in this study were deposited in the DDBJ, EMBL, and GenBank databases (Mesodinium rubrum, LC341273; Mesodinium sp., LC333818; Chroomonas sp., LC334060; Hemiselmis sp., LC334059; Teleaulax acuta, LC334057; Teleaulax amphioxeia, LC334056; and Urgorri complanatus, LC334058). 


\section{References}

1. Leppanen, J. M. \& Bruun, J. E. The role of pelagic ciliates including the autotrophic Mesodinium rubrum during the spring bloom of 1982 in the open northern Baltic proper. Ophelia 4, 147-157 (1986).

2. Sanders, R. W. Seasonal distributions of the photosynthesizing ciliates Laboea strobila and Myrionecta rubra (=Mesodinium rubrum) in an estuary of the Gulf of Maine. Aquat. Microb. Ecol. 9, 237-242 (1995).

3. Lindholm, T. Mesodinium rubrum-a unique photosynthetic ciliate. Adv. Aquat. Microbiol. 3, 1-48 (1985).

4. Hayes, G. C., Purdie, D. A. \& Williams, J. A. The distribution of ichthyoplankton in Southampton Water in response to low oxygen levels produced by a Mesodinium rubrum bloom. J. Fish Biol. 34, 811-813 (1989).

5. Liu, H. et al. Potential risk of Mesodinium rubrum bloom in the aquaculture area of Dapeng'ao cove, China: diurnal changes in the ciliate community structure in the surface water. Oceanologia 54, 109-117 (2012).

6. Johnson, M. D., Oldach, D., Delwiche, C. F. \& Stoecker, D. K. Retention of transcriptionally active cryptophyte nuclei by the ciliate Myrionecta rubra. Nature 445, 426-428 (2007).

7. Mouritsen, L. T. \& Richardson, K. Vertical microscale patchiness in nano- and microplankton distributions in a stratified estuary. J. Plankton Res. 25, 783-797 (2003).

8. Sjöqvist, C. O. \& Lindholm, T. J. Natural co-occurrence of Dinophysis acuminata (Dinoflagellata) and Mesodinium rubrum (Ciliophora) in thin layers in a coastal inlet. J. Eukaryot. Microbiol. 58, 365-372 (2011).

9. Lips, U. \& Lips, I. Bimodal distribution patterns of motile phytoplankton in relation to physical processes and stratification (Gulf of Finland, Baltic Sea). Deep-Sea Res. II. 101, 107-119 (2014).

10. Velo-Suárez, L., González-Gil, S., Pazos, Y. \& Reguera, B. The growth season of Dinophysis acuminata in an upwelling system embayment: a conceptual model based on in situ measurements. Deep-Sea Res. II 101, 141-151 (2014).

11. Qiu, D., Huang, L. \& Lin, S. Cryptophyte farming by symbiotic ciliate host detected in situ. Proc. Natl. Acad. Sci. USA 113, 12208-12213(2016).

12. Johnson, M. D. et al. Mesodinium rubrum: The symbiosis that wasn't. Proc. Natl. Acad. Sci. USA 114, E1040-E1042 (2017).

13. Nishitani, G. et al. High-level congruence of Myrionecta rubra prey and Dinophysis species plastid identities as revealed by genetic analyses of isolates from Japanese coastal waters. Appl. Environ. Microbiol. 76, 2791-2798 (2010).

14. Herfort, L. et al. Myrionecta rubra population genetic diversity and its cryptophyte chloroplast specificity in recurrent red tides in the Columbia River estuary. Aquat. Microb. Ecol. 62, 85-97 (2011).

15. Herfort, L. et al. Use of highly specific molecular markers reveals positive correlation between abundances of Mesodinium cf. major and its preferred prey, Teleaulax amphioxeia, during red water blooms in the Columbia River estuary. J. Eukaryot. Microbiol. 64, 740-755 (2017).

16. Garcia-Cuetos, L., Moestrup, Ø. \& Hansen, P. J. Studies on the genus Mesodinium II. Ultrastructural and molecular investigations of five marine species help clarifying the taxonomy. J. Eukaryot. Microbiol. 59, 374-400 (2012).

17. Moestrup, Ø., Garcia-Cuetos, L., Hansen, P. J. \& Fenchel, T. Studies on the genus Mesodinium I: ultrastructure and description of Mesodinium chamaeleon n. sp., a benthic marine species with green or red chloroplasts. J. Eukaryot. Microbiol. 59, 20-39 (2012).

18. Nam, S. W., Shin, W., Kang, M., Yih, W. \& Park, M. G. Ultrastructure and molecular phylogeny of Mesodinium coatsi sp. nov., a benthic marine ciliate. J. Eukaryot. Microbiol. 62, 102-120 (2015).

19. Moeller, H. V. \& Johnson, M. D. Preferential plastid retention by the acquired phototroph Mesodinium chamaeleon. J. Eukaryot. Microbiol. 65, 148-158 (2018).

20. Johnson, M. D. et al. The genetic diversity of Mesodinium and associated cryptophytes. Front. Microbiol. 7, https://doi.org/10.3389/ fmicb.2016.02017 (2016).

21. Laza-Martínez, A. Urgorri complanatus gen. et sp. nov. (Cryptophyceae), a red-tide-forming species in brackish waters. J. Phycol. 48, 423-435 (2012).

22. Hoef-Emden, K. Molecular phylogeny of phycocyanin-containing cryptophytes: evolution of biliproteins and geographical distribution. J. Phycol. 44, 985-993 (2008).

23. Gustafson, D. E. Jr., Stoecker, D. K., Johnson, M. D., Van Heukelem, W. F. \& Sneider, K. Cryptophyte algae are robbed of their organelles by the marine ciliate Mesodinium rubrum. Nature 405, 1049-1052 (2000).

24. Hansen, P. J. \& Fenchel, T. The bloom-forming ciliate Mesodinium rubrum harbours a single permanent endosymbiont. Mar. Biol. Res. 2, 169-177 (2006).

25. Johnson, M. D., Tengs, T., Oldach, D. \& Stoecker, D. K. Sequestration, performance, and functional control of cryptophyte plastids in the ciliate Myrionecta rubra (Ciliophora). J. Phycol. 42, 1235-1246 (2006).

26. Park, J. S., Myung, G., Kim, H. S., Cho, B. C. \& Yih, W. Growth responses of the marine photosynthetic ciliate Myrionecta rubra to different cryptomonad strains. Aquat. Microb. Ecol. 48, 83-90 (2007).

27. Hansen, P. J., Moldrup, M., Tarangkoon, W., Garcia-Cuetos, L. \& Moestrup, Ø. Direct evidence for symbiont sequestration in the marine red tide ciliate Mesodinium rubrum. Aquat. Microb. Ecol. 66, 63-75 (2012).

28. Peltomaa, E. \& Johnson, M. D. Mesodinium rubrum exhibits genus-level but not species-level cryptophyte prey selection. Aquat. Microb. Ecol. 78, 147-159 (2017).

29. Yih, W. et al. The red-tide ciliate Mesodinium rubrum in Korean coastal waters. Harmful Algae 30(Suppl. 1), S53-S61 (2013).

30. Johnson, M. D., Stoecker, D. K. \& Marshall, H. G. Seasonal dynamics of Mesodinium rubrum in Chesapeake Bay. J. Plankton Res. 35, 877-893 (2013).

31. Yih, W., Kim, H. S., Jeong, H. J., Myung, G. \& Kim, Y. G. Ingestion of cryptophyte cells by the marine photosynthetic ciliate Mesodinium rubrum. Aquat. Microb. Ecol. 36, 165-170 (2004).

32. Nagai, S., Nishitani, G., Tomaru, Y., Sakiyama, S. \& Kamiyama, T. Predation by the toxic dinoflagellate Dinophysis fortii on the ciliate Myrionecta rubra and observation of sequestration of ciliate chloroplasts. J. Phycol. 44, 909-922 (2008).

33. Tong, M., Smith, J. L., Kulis, D. M. \& Anderson, D. M. Role of dissolved nitrate and phosphate in isolates of Mesodinium rubrum and toxin-producing Dinophysis acuminata. Aquat. Microb. Ecol. 75, 169-185 (2015).

34. Johnson, M. D. \& Stoecker, D. K. Role of feeding in growth and photophysiology of Myrionecta rubra. Aquat. Microb. Ecol. 39, 303-312 (2005).

35. Nishitani, G. et al. Multiple plastids collected by the dinoflagellate Dinophysis mitra through kleptoplastidy. Appl. Environ. Microbiol. 78, 813-821 (2012).

36. Kumar, S., Stecher, G. \& Tamura, K. MEGA7: Molecular Evolutionary Genetics Analysis version 7.0 for bigger datasets. Mol. Biol. Evol. 33, 1870-1874 (2016).

\section{Acknowledgements}

The authors thank Toshinori Fukui, Tottori Prefectural Fisheries Research Center, and Akihiro Mori and Akihiro Maeda, Environmental Sanitation Research Center of Tottori Prefecture, for their cooperation in field sampling. We also thank Setsuko Sakamoto and Kazuo Abe, National Research Institute of Fisheries and Environment of Inland Sea, for assistance with nutrient analyses, Satoshi Nagai, National Research Institute of Fisheries Science, for providing T. amphioxeia culture, and Waka Sato-Okoshi, Tohoku University, for helpful discussion. This study was supported by a Grant-in-Aid for Scientific Research (C) from the Japan Society for the Promotion of Science (JSPS) (KAKENHI; No. 17K07886). 


\section{Author Contributions}

G.N. and M.Y. conceived and designed the study. M.Y. performed field sampling, took photographs, enumerated cells, and conducted culture experiments of Mesodinium. G.N. performed primer design, PCR, sequencing, and phylogeny. G.N. drafted the manuscript, and M.Y. contributed data and revised the manuscript. Both authors read and approved the final manuscript.

\section{Additional Information}

Supplementary information accompanies this paper at https://doi.org/10.1038/s41598-018-35629-4.

Competing Interests: The authors declare no competing interests.

Publisher's note: Springer Nature remains neutral with regard to jurisdictional claims in published maps and institutional affiliations.

(c) (i) Open Access This article is licensed under a Creative Commons Attribution 4.0 International License, which permits use, sharing, adaptation, distribution and reproduction in any medium or format, as long as you give appropriate credit to the original author(s) and the source, provide a link to the Creative Commons license, and indicate if changes were made. The images or other third party material in this article are included in the article's Creative Commons license, unless indicated otherwise in a credit line to the material. If material is not included in the article's Creative Commons license and your intended use is not permitted by statutory regulation or exceeds the permitted use, you will need to obtain permission directly from the copyright holder. To view a copy of this license, visit http://creativecommons.org/licenses/by/4.0/.

(C) The Author(s) 2018 